\title{
Schiff's bases metal complexes in biological applications
}

\begin{abstract}
The article gives an insight into the use of Schiff's bases as the ligand for the synthesis of various metal complexes. The coordination chemistry is dominated by the utilization of Schiff's bases as ligands in the study of metal complexes. Further these metal complexes are used extensively in biological field along with many other applications. Several metal complexes of schiff's bases have been used as antimicrobial agents, DNA cleaving agents, as sensors etc. Thus a glimpse of such several applications has been provided in this article.

Keywords: schiff's bases, metal complexes, chemistry, antimicrobial, DNA cleaving agents
\end{abstract}

Volume 5 Issue I - 2017

\author{
Ajaykumar D Kulkarni \\ Department of Applied Sciences, MIT Academy of Engineering, \\ India \\ Correspondence: Ajaykumar D Kulkarni, Department of \\ Applied Sciences, MIT Academy of Engineering (An Autonomous \\ Institute Afiliated to Savitribai Phule Pune University), Dehu \\ Phata, Alandi (D), Pune, 4I2I05, India, \\ Email ajaykumarbp@gmail.com
}

Received: May 23, 2017 | Published: June 07, 2017

\section{Mini review}

"The Ever Increasing Applications of Metal Complexes in Various Fields of Science is the Driving Force for the Research and Development in Coordination Chemistry"

Coordination chemistry was founded by Swiss scientist A. Werner (1866-1919), who won the Nobel Prize in 1913. Great contribution was further made by Russian chemist L.A. Chugaev (1873-1922). Coordination (complex) entities consist of a cationic, anionic or neutral complex. Those substances, whose molecules contain a central atom (cations), coordinated with ligands (anions, neutral molecules or radicals) can be considered as coordination or complex entities ${ }^{1}$ and the area of inorganic chemistry, studying joint behavior of cations and their ligands was termed as coordination chemistry. ${ }^{2}$

The main direction of metal-complex chemistry in 21 st century is emphasized as "From Biology to Nanotechnology". ${ }^{3}$ B-Diketones and their analogues, diketonate complexes, ${ }^{4}$ azomethinic and heterocyclic ligands remain "eternal". Creation of new hard-soft ligand systems is attractive..$^{5-8}$ Creation of hybrid biologically perspective ligating systems is also interesting. ${ }^{9-13}$ The principal goal is to work not only for theoretical, but also for practically useful coordination chemistry (competitive coordination), taking into account an operated creation of polyfunctional materials (for instance, selective electrodes). Modern achievements in coordination chemistry are detailed. ${ }^{14}$

Coordination chemistry is dominated by the utilization of Schiff bases as ligands ${ }^{15}$ due to its chelating ability and complexing ability towards transition metal ions. Schiff base compounds containing imine group $(-\mathrm{RC}=\mathrm{N}-)$ are usually formed by the condensation of a primary amine/diamine with an active carbonyl compound. The Schiff base ligands and their complexes have significant importance in chemistry, and every year a number of reports are published on the preparation of these compounds and their application in chemical reactions. ${ }^{16}$ The Schiff base compounds and their complexes are widely applied in enantioselective cyclopropanation of styrenes, ${ }^{17}$ asymmetric addition of cyanide to aldehydes ${ }^{18}$ asymmetric aziridination of olefins, ${ }^{19}$ enantioselective epoxidation, ${ }^{19,20}$ regio-selective ring opening of epoxides $^{21}$ and as a membrane in ion selective electrode. ${ }^{22-26}$ The metal complexes of Schiff bases also finds applications in versatile catalytic reactions for organic synthesis, ${ }^{27-30}$ degradation of organic substances ${ }^{31}$ in radiopharmaceuticals, ${ }^{32}$ their ability to reversibly bind oxygen ${ }^{33}$ and photochromic properties. ${ }^{34}$ Schiff base metal complexes have also found greater applications in biological field. Schiff bases have been reported to exhibit a variety of biological actions by virtue of the azomethine linkage, which is responsible for various antibacterial, antifungal, herbicidal, clinical and analytical activities. ${ }^{35-38}$ Recently, there has been tremendous interest in studies related to the interaction of transition metal ions with nucleic acid because of their relevance in the development of new reagents for biotechnology and medicine. ${ }^{39}$ There has also been substantial interest in the rational design of novel transition metal complexes, which bind and cleave duplex DNA with high sequence and structure selectivity. ${ }^{40-42}$

\section{Acknowledgments}

None.

\section{Conflicts of interest}

The authors declare no conflicts of interest related to this article.

\section{Funding}

None.

\section{References}

1. AA Grinberg. Introduction in Chemistry of Complex Compounds. Leningrad, Germany: Khimiya; 1971. pp. 386.

2. VV Skopenko, A Yu Tsivadze, LI Savranskii, et al. Coordination Chemistry. Moscow, Russia: Akademkniga; 2007.

3. JA McCleverty, TJ Meyer. In Comprehensive Coordination Chemistry II. 2nd edn. Oxford-New York: Elsevier-Pergamon Press; 2003. p. $1-10$.

4. VV Skopenko, BM Amirkhanov, TYu Sliva, et al. Phosphate tungsten bronzes. Usp Khim. 2004;73(8):814-832.

5. AD Garnovskii, EV Sennikova. Aryl and 1,3-dioxoindanyl derivatives of azoles and azines (review). Chem Heterocyl Comp. 2007;43(11):13591373.

6. EV Sennikova, IG Borodkina, AS Antsyshkina, et al. 2-(2-Pyridyl) indandione-1,3 and its zinc(II) and nickel(II) complexes:Synthesis and physicochemical characterization. Russ $J$ Inorg Chem. 2006;51(10):1548-1551. 
7. EV Sennikova, OYu Korshunov, GS Borodkin, et al. 2-(2-pyridyl)-3thioindan-1-one:Synthesis, tautomerism, and complexing properties. Russ J Gener Chem. 2007;77(10):1802-1806.

8. EV Sennikova, AS Antsyshkina, GG Sadikov, et al. The ever increasing applications of metal complexes in various fields of science is the riving force for the research and development in coordination chemistry. Russ J Coord Chem. 2008;34(5):315.

9. LH Minacheva, IS Ivanova, AV Dorokhov, et al. Tsivadze. Dokl Akad Nauk Ser Khim. 2004;398(1):62.

10. IS Ivanova, AV Dorokhov, EN Pyatova, et al. Alkalli Metal Complexes with N-(4-Benzo-15-Crown-5)-2-(Amino-N-tosyl)-phenylaldimine. Tsivadze, Koord. Khim. 2005;31(7):483-488.

11. LH Minacheva, IS Ivanova, AV Dorokhov, et al. Tsivadze Koord Khim 2006;32(3):174.

12. AS Burlov, AV Tsukanov, GS Borodkin, et al. Obsch Khim 2006;76(6):1037.

13. AV Dorohov, DYu Chernyshov, AS Burlov, et al. Synchrotron powder diffraction in a systematic study of 4'-[2-(tosylamino) benzylideneamino]-2,3-benzo-15-crown-5 complexes. Acta Crystallogr B. 2007;63:402-410.

14. 38th International Conference on Coordination Chemistry (ICCC38) Israel: Jerusalem; 2008.

15. N Nimitsirwat, C Vernon. J Am Chem Soc. 2004;32:126.

16. M Shamsipur, AR Ghiasvand, H Sharghi, et al. Anal Chim Acta. 2000;408:271.

17. M Qiu, G Liu, X Yiao. Chin J Catal. 2001;22:77.

18. ZH Yang, LX Wang, ZH Zhou, et al. Synthesis of new chiral Schiff bases and their application in the asymmetric trimethylsilylcyanation of aromatic aldehydes. Tetrahedron: Asymmetry. 2001;12(11):1579-1582.

19. JO Kenneth, JW Shiow, JB Cynthia. Alkene aziridination and epoxidation catalyzed by chiral metal salen complexes. Tetrahedron Letters. 1992;33(8):1001-1004.

20. EJ Jacobsen, W Zhang, ML Guler. Highly enantioselective epoxidation catalysts derived from 1,2-diaminocyclohexane. J Am Chem Soc. 1991;113(18):7063-7064.

21. H Sharghi, H Naeimi. Schiff-Base Complexes of Metal(II) as New Catalysts in the High-Regioselective Conversion of Epoxides to Halo Alcohols by Means of Elemental Halogen. BCSJ. 1999;72(7):15251531.

22. M Shamsipur, S Sadeghi, H Naeimi, et al. Simple Synthesis of $2-$ Thioglycosyl Derivatives of Pyridine N-Oxide. Polish Journal of Chemistry. 2000;74(2):231.

23. N Alizadeh, S Ershad, H Naeimi, et al. J Anal Chem. 1999;365:511.

24. MM Ardakany, AA Ensafi, H Naeimi, et al. Sensors Actuotors B 2003:441.

25. AR Khorrami, H Naeimi, AR Fakhari. Determination of nickel in natural waters by FAAS after sorption on octadecyl silica membrane disks modified with a recently synthesized Schiff's base. Talanta. 2004;64(1):13-17.
26. M Shamsipur, M Yousefi, M Hosseini, et al.Iodide Ion-Selective PVC Membrane Electrode Based on a Recently Synthesized Salen-Mn(II) Complex. Anal Chem. 2001;73(2):2869.

27. G Henrici Olive, S Olive. The Chemistry of Catalyzed Hydrogenation of Carbon Monoxide. USA: Springer Berlin; 1984. pp. 152.

28. A Nashinaga, H Ohara, $\mathrm{H}$ Tomita, et al. Mechanism of Co(salen)catalyzed oxygenolysis of indole ring as a model for the tryptophan-2,3dioxygenase reaction. Tetrahedron Letters. 1983;24(2):213-216.

29. K Maruyama, K Kubo, Y Toda, et al. Highly selective aldol reaction of dibenzoylmethanes with formaldehyde catalyzed by cobalt schiff base complex under neutral conditions. Tetrahedron Lett. 1995;36(31):5609_ 5612 .

30. T Nakamura, K Niwa, M Fujiwara, et al. Novel Dinuclear Manganese(III) Complexes with Tridentate and Bridging Tetradentate Schiff Base Ligands:Preparation, Properties and Catalase-like Function. Chemistry Letters. 1999;28(10):1067-1068.

31. YK Choi, WS Kim, KI Chung, et al. Catalytic effect of transition metal(II)-N,N'-bis(naphthaldehyde)diimines on reduction of thionyl chloride. Microchemical Journal. 2000;65(1):3-15.

32. MA Green, H Luo, PE Fanwick. Synthesis and Structure of a Novel $\mathrm{Cu}$ (II) Complex with a Monoprotic Tetradentate Schiff Base Ligand. Inorganic Chemistry. 1998;37(5):1127-1130.

33. RD Jones, RD Summerville, F Basolo (1979) Synthetic oxygen carriers related to biological systems. Chem Rev. 1979;79(2):139-179.

34. JD Margerum, LJ Miller. Photochromism. New York: Interscience Wiley; 1971. pp. 569.

35. AA Jarrahpour, M Motamedifar, K Pakshir, et al. Synthesis of Novel Azo Schiff Bases and Their Antibacterial and Antifungal Activities. Molecules. 2004;9(10):815-824.

36. AM Mahindra, JM Fisher, Rabinovitz. Bathocuproine sulphonate:a tissue culture-compatible indicator of copper-mediated toxicity. Nature (London). 1983;303:64-65.

37. PR Palet, BT Thaker, S Zele. Preparation and characterisation of some lanthanide complexes involving a heterocyclic $\sim$ - diketone. Ind J Chem. 1999;38 A:563-567.

38. TL Yang, XS Tai, WW Qin, et al. Anal Sci. 2004;20:493.

39. V Uma, VG Vaidyanathan, BU Nair (2005) Synthesis, Structure, and DNA Binding Studies of Copper(II) Complexes of Terpyridine Derivatives. Bull Chem Soc Jpn. 2005;78(5):845-850.

40. BH Geierstanger, M Marksich, PB Dervan, DE Wemmer (1994) Design of a G.C-specific DNA minor groove-binding peptide. Science. 1994;266(5184):646-650.

41. C Liu, J Zhou, Q Li, L Wang, Z Liao, H Xu (1999) DNA damage by copper(II) complexes:coordination-structural dependence of reactivities. J Inorg Biochem. 1999;75(3):233-240.

42. G Prativiel, J Bernadou, B Meunier. Carbon-Hydrogen Bonds of DNA Sugar Units as Targets for Chemical Nucleases and Drugs. Angew Chem Int Ed Engl. 1995;34(7):746-769. 